\title{
A BIBLIOGRAPHY OF THE WORKS OF J. D. Y. PEEL (1941-2015)
}

This bibliography revises and expands the list compiled by T. C. McCaskie that was published in T. Falola (ed.) (2005) Christianity and Social Change in Africa: essays in honor of J. D. Y. Peel (Durham NC: Carolina Academic Press). I am particularly grateful to Wale Adebanwi, Olufunke Adeboye, Yetunde Aina and Bolanle Awe for leads and information, and I would also like to thank Francis Peel for access to his late father's collection of off-prints.

1966

Review of M. J. C. Calley, God's People: West Indian Pentecostal sects in England and R. L. Wishlade, Sectarianism in Southern Nyasaland. British Journal of Sociology 17 (3): 328.

'Religious change in Yorubaland', Africa 37 (3): 292-306; facsimile reprint in O. Pettersson (ed.), Religion and Society: papers in cultural anthropology. Lund: Studentliteratur, pp. 33-47.

Review of S. Fuchs, Rebellious Prophets: a study of messianic movements in Indian religions. British Journal of Sociology 18 (2): 223.

Review of J. A. Prades, La Sociologie de la religion chez Max Weber: Essai d'analyse et de critique de la méthode. British Journal of Sociology 18 (3): 340.

1968

Aladura: a religious movement among the Yoruba. London: Oxford University Press for the International African Institute, pp. xii +338 .

'Syncretism and religious change', Comparative Studies in Society and History 10 (2): $121-41$.

'The Aladura movement in Western Nigeria', Tarikh 3: 48-55.

'Spencer and the Neo-Evolutionists', Sociology 3 (2): 173-91; reprinted in R. S. Denisoff, O. Callahan and M. H. Levine (eds) (1974), Theories and Paradigms in Contemporary Sociology. Itasca IL: F. E. Peacock Publishers.

(C) International African Institute 2016 
'Understanding alien belief-systems', British Journal of Sociology 20 (1): 69-84; reprinted and translated as 'Was heißt "fremde Glaubenssysteme verstehen"?' in H. G. Kippenberg and B. Luchesi (eds) (1978), Magie: die Sozialwissenschaftliche Kontroverse über das Verstehen fremden Denkens. Frankfurt-am-Main: Suhrkamp, pp. 150-73.

Review of N. Long, Social Change and the Individual: a study of the social and religious responses to innovation in a Zambian rural community. Sociology 3 (3): 440.

1970

'Reply to Beattie's comment on "Understanding alien belief-systems", British Journal of Sociology 21 (2): 224-6.

Review of S. Andreski, Herbert Spencer, the Principles of Sociology. British Journal of Sociology 21 (1): 109-10.

Review of D. Barrett, Schism and Renewal in Africa: an analysis of six thousand contemporary religious movements. Sociology 4 (2): 249-51.

Review of A. G. Keller and M. R. Davie (eds), Essays of William Graham Sumner (reprint, 2 vols). Sociology 4 (1): 132.

Review of R. Smith, Kingdoms of the Yoruba. Africa 40 (1): 84.

Herbert Spencer: the evolution of a sociologist. London and New York NY: Heinemann and Basic Books; reprinted Aldershot: Gregg Revivals, 1992, pp. 338.

'Okediji's Review of Aladura: a religious movement among the Yoruba: a comment', American Anthropologist 73 (6): 1481-2.

Review of R. W. Friedrichs, A Sociology of Sociology. British Journal of Sociology 22 (3): 336-7.

Review of E. Krapf-Askari, Yoruba Towns and Cities: an enquiry into the nature of urban social phenomena. Sociology 5 (2): 272.

'Introduction' (vii-li), and selection of Herbert Spencer on Social Evolution. Heritage of Sociology series. Chicago IL: University of Chicago Press; reprinted Chicago IL: Midway Reprints, 1982, pp. $1 \mathrm{i}+270$.

Review of V. W. Turner, Colonialism in Africa 1870-1960, vol. 3: Profiles of Change: African society and colonial rule. British Journal of Sociology 23 (1): $128-9$. 
Review of M. Wilson, Religion and the Transformation of Society: a study of social change in Africa. Sociology 6 (2): 329-30.

1973

'Cultural factors in the contemporary theory of development', Archives Européennes de Sociologie 14 (2): 283-303.

'The religious transformation of Africa in a Weberian perspective' in The Contemporary Metamorphosis of Religion? Métamorphose contemporaine des phénomènes religieux? Acts of the 12th Conference: International Conference on Sociology of Religion. Lille: Edition du Secrétariat CISR, pp. 337-52.

Review of S. Andreski, Herbert Spencer: structure, function and evolution. British Journal of Sociology 24 (2): 268.

Review of D. B. Cruise O'Brian, The Mourides of Senegal: the political and economic organization of an Islamic brotherhood. Journal of Development Studies 9 (2): $333-4$.

Review of W. LaBarre, The Ghost Dance: origins of religion. Sociology 7 (2): $281-2$.

Review of K. W. J. Post and G. D. Jenkins, The Price of Liberty: personality and politics in colonial Nigeria and of C. Allen and R. W. Johnson (eds) African Perspectives: papers in the history, politics and economics of Africa presented to Thomas Hodgkin. Journal of Development Studies 10 (1): 122-4.

1974

Review of B. R. Wilson, Magic and the Millennium. British Journal of Sociology 25 (2): $255-7$.

'Spencer, Herbert', in C. C. Gillispie (ed.), Dictionary of Scientific Biography. New York NY: Scribner, vol. 12, pp. 569-72.

Review of L. Mair, African Societies. British Journal of Sociology 26 (2): 254-5.

1976

[with R. Horton] 'Conversion and confusion: a rejoinder on Christianity in Eastern Nigeria’, Canadian Journal of African Studies 10 (3): 481-98. 
'The significance of culture for development studies', Bulletin of the Institute of Development Studies 8 (2): 8-11.

'Colour in class' [review of E. H. Berman (ed.), African Reactions to Missionary Education and of C. H. Lyons, To Wash an Aethiop White: British ideas about Black African educability 1530-1960], Journal of African History 17 (3): 467-9.

Review of P. C. Lloyd, Power and Independence: urban Africans' perception of social inequality and of P. Cole, Traditional and Modern Elites in the Politics of Lagos. British Journal of Sociology 27 (2): 290-1.

1977

'Conversion and tradition in two African societies: Ijebu and Buganda', Past and Present 77: 108-41.

Review of S. R. Barrett, Two Villages on Stilts: economic and family change in Nigeria. Canadian Journal of African Studies 11 (1): 145-7.

Review of R. Fox. A. S. A. Studies, vol. 1: Biosocial anthropology, of M. Bloch, A. S. A. Studies, vol 2: Marxist analysis and social anthropology, and of R. Willis, A. S. A. Studies, vol 3: The interpretation of symbolism. British Journal of Sociology 28 (1): 111-12.

\section{8}

'Olaju: a Yoruba concept of development', Journal of Development Studies 14 (2): 139-65.

'The Christianization of African society: some possible models' in E. FasholéLuke, R. Gray, A. Hastings and G. Tasie (eds), Christianity in Independent Africa. London: Collings, pp. 443-54.

'Two cheers for empiricism: or, what is the relevance of the history of sociology to its current practice?' [review article], Sociology 12 (2): 347-59; also in M. Kajitani (ed.) (1982) 社会科学の史的展開: 国際学会論集 Shakai kagaku no shiteki tenkai [Approaches to the History of the Social Sciences]. Tokyo: Gakubunsha.

Review of D. E. Baldwin and C. M. Baldwin, The Yoruba of Southwestern Nigeria: an indexed bibliography. Africa 48 (3): 314.

Review of J. Ben-David and T. Nichols Clark, Culture and its Creators: essays in honor of Edward Shils. Bulletin of the Atomic Scientists 34 (3): 61-2.

Review of R. F. Thompson, Black Gods and Kings: Yoruba art at UCLA and of D. Duerden, African Art and Literature: the invisible present. African Affairs 77 (308): 410-11. 
'Kings, titles and quarters: a conjectural history of Ilesha. Part I: The traditions reviewed', History in Africa 6: 109-53.

Review of S. R. Barrett, The Rise and Fall of an African Utopia: a wealthy theocracy in comparative perspective. Man (N.S.) 14 (1): 172-3.

Review of W. De Craemer, The Jamaa and the Church: a Bantu Catholic movement in Zaire. American Journal of Sociology 85 (3): 698-700.

1980

'Editorial', Africa 50 (3): 243-7.

'Editorial', Africa 50 (4): 335-40.

'Inequality and action: the forms of Ijesha social conflict', Canadian Journal of African Studies 14 (3): 473-502.

'Kings, titles and quarters: a conjectural history of Ilesha. Part II: Institutional growth', History in Africa 7: 225-57.

'Urbanization and urban history in West Africa' [review of P. C. W. Gutkind, Urban Anthropology, of J. Gugler and W. G. Flanagan, Urbanization and Social Change in West Africa, of H. Wolpe, Urban Politics in Nigeria: a study of Port Harcourt, of P. H. Baker, Urbanization and Political Change: the politics of Lagos, 1917-1967, of E. Schildkrout, People of the Zongo: the transformation of ethnic identities in Ghana and of B. E. Harrell-Bond, A. M. Howard and D. E. Skinner, Community Leadership and the Transformation of Freetown (1801-1976)], Journal of African History 21 (2): 269-77.

Review of A. Hastings, A History of African Christianity 1950-1975 and of G. Bond, W. Johnson and S. S. Walker (eds) African Christianity: patterns of religious continuity. Africa 50 (3): 323-6.

1981

[with P. Richards] 'Introduction', Africa 51 (2): 553-6. Special issue on 'Rice and yams in West Africa'.

1982

[with T. O. Ranger] 'Introduction', Africa 52 (3): v-viii; facsimile reprint in J. D. Y. Peel and T. O. Ranger (eds) (1983) Past and Present in Zimbabwe. Manchester: 
Manchester University Press in association with Africa: Journal of the International African Institute.

'Church history and a Christian life' [reviews of O. U. Kalu (ed.), The History of Christianity in West Africa and of E. Isichei Entirely for God: the life of Michael Iwere Tansi], Journal of African History 23 (2): 275-6.

Review of S. Miers and I. Kopytoff (eds) Slavery in Africa: historical and anthropological perspectives. British Journal of Sociology 33 (2): 289-90.

\section{3}

Ijeshas and Nigerians: the incorporation of a Yoruba kingdom, 1890s-1970s. African Studies Series 39. Cambridge: Cambridge University Press, pp. xiv +346.

[co-editor with T. O. Ranger] Past and Present in Zimbabwe. Manchester: Manchester University Press in association with Africa: Journal of the International African Institute. Facsimile reprint of Africa 52 (3) (1982), pp. viii +120 .

Review of T. O. Beidelman, Colonial Evangelism: a socio-historical study of an East African mission at the grassroots. Bulletin of the School of Oriental and African Studies 46 (2): 408-9.

Review of L. De Heusch, Rois nés d'un coeur de vache. Man (N.S.) 18 (3): 617-18.

Review of J. W. Fernandez, Bwiti: an ethnography of the religious imagination in Africa. American Ethnologist 10 (4): 791-2.

Review of E. Isichei (ed.) Varieties of Christian Experience in Nigeria. Journal of African History 24 (3): 421.

Review of R. W. Wyllie, Spiritism in Ghana: a study of new religious movements. Africa 53 (3): 91-2.

1984

'Introduction', Africa 54 (3): 2-4. Special issue on 'Interventions of the state'.

'Making history: the past in the Ijesha present', Man (N.S.) 19 (1): 111-32.

'Social and cultural change' in M. Crowder (ed.), Cambridge History of Africa. Vol. 8: c.1940-c.1975. Cambridge: Cambridge University Press, pp. 142-91, 827-32, 914-21. 
Review of J. Zwernemann, Culture History and African Anthropology: a century of research in Germany and Austria. Man (N.S.) 19 (4): 707-8.

1985

'Auguste Comte' in A. Kuper and J. Kuper (eds), The Social Science Encyclopedia. London: Routledge; reprinted as 'Comte, Auguste (1798-1857)' in 2nd edition (1996), pp. 120-1 and in J. Kuper (ed.) (1987) Key Thinkers, Past and Present. London: Routledge, pp. 39-41.

'Herbert Spencer' in A. Kuper and J. Kuper (eds), The Social Science Encyclopedia. London: Routledge.

[co-edited with C. C. Stewart] Popular Islam South of the Sahara. Manchester: Manchester University Press in association with Africa: Journal of the International African Institute. Facsimile reprint of Africa 55 (4) (1985), pp. 102.

Review of M. Augé, Génie du paganisme. Africa 55 (1): 96-7.

Review of C. Camic, Experience and Enlightenment: socialization for cultural change in eighteenth-century Scotland. American Journal of Sociology 91 (1): $161-3$.

Review of W. MacGaffey, Modern Kongo Prophets: religion in a plural society. Bulletin of the School of Oriental and African Studies 48 (1): 192-3.

Review of G. W. Stocking, Functionalism Historicized: essays on British social anthropology. Isis 76 (4): 619-20.

1986

Review of S. S. Berry, Fathers Work for their Sons: accumulation, mobility and class formation in an extended Yoruba community. Journal of Development Studies 22 (4): $782-4$.

Review of M. Bloch, From Blessing to Violence: history and ideology in the circumcision ritual of the Merina of Madagascar. Current Anthropology 27 (4): 357-8.

Review of M. Bulmer, The Chicago School of Sociology: institutionalization, diversity and the rise of sociological research. British Journal of Sociology 37 (4): 603-4.

Review of H. J. Drewal and M. Thompson Drewal, Gelede: art and female power among the Yoruba. Africa 56 (3): 372-3.

Review of T. R. Wright, The Religion of Humanity: the impact of Comtean positivism on Victorian Britain. Sociology 20 (4): 661-2. 
1987

'History, culture and the comparative method: a West African puzzle' in L. Holy (ed.), Comparative Anthropology. Oxford: Basil Blackwell, pp. 88-118. Revised version in J. Peel, Christianity, Islam, and Orișa Religion (2016), pp. 17-37, $236-40$.

'Progression and recursion in African social thought' in African Futures: Twentyfifth Anniversary Conference: proceedings of a conference held in the Centre of African Studies, University of Edinburgh, 9-11 December 1987. Seminar Proceedings 28. Edinburgh: University of Edinburgh, Centre of African Studies, pp. 275-91.

Review of P. B. Clarke, West Africa and Christianity. Journal of African History 28 (1): 173.

Review of W. van Binsbergen and M. Schoffeleers (eds), Theoretical Explorations in African Religion. Africa 57: 400-1.

Review of K. Mann, Marrying Well: marriage, status and social change among the educated elite in colonial Lagos. Journal of Imperial and Commonwealth History 15 (2): 194-5.

1988

'Two northerners contrasted in their visions of Nigerian unity' [review of J. I. Elaigwu, Gowon: the biography of a soldier statesman and of J. N. Paden, Ahmadu Bello, Sardauna of Sokoto: values and leadership in Nigeria], Canadian Journal of African Studies 22 (1): 144-8.

Review of L. White, Magomero: the portrait of an African village. Man (N.S.) 23 (1): 193-4.

1989

'The cultural work of Yoruba ethnogenesis' in E. Tonkin, M. McDonald and M. K. Chapman (eds), History and Ethnicity. ASA Monograph 27. London: Tavistock, pp. 198-215.

Review of R. I. J. Hackett (ed.), New Religious Movements in Nigeria. Journal of Religion in Africa 19 (2): 188-90.

Review of R. Hallgren, The Good Things in Life: a study of the traditional religious culture of the Yoruba people. Ethnos 54 (3-4): 254.

Review of W. James and D. H. Johnson, Vernacular Christianity: essays in the social anthropology of religion presented to Godfrey Lienhardt. Africa 59 (3): 422-4. 
1990

'Against the motion (1)' and [with M. Strathern, J. Spencer, C. Toren et al.] 'The debate' in T. Ingold (ed.), The Concept of Society is Theoretically Obsolete: a debate held in the Muriel Stott Centre, John Rylands University Library of Manchester on 28th October 1989. Manchester: University of Manchester, Group for Debates in Anthropological Theory, pp. 11-16; 'Part II: The debate', Peel contributions on pp. 28, 29, 31-2, 34-5, 38-9; reprinted in T. Ingold (ed.) (1996), Key Debates in Anthropology. London and New York NY: Routledge, pp. 55-60, 83-98.

'Perspectives on nationalism in Black Africa: a Nigerian case-study' in P. E. H. Hair (ed.), Black Africa in Time-Perspective: four talks on wide historical themes. Liverpool: Liverpool University Press, pp. 57-75.

'Poverty and sacrifice in nineteenth-century Yorubaland: a critique of Iliffe's thesis', Journal of African History 31 (3): 465-84.

'The pastor and the Babalawo: the interaction of religions in nineteenth-century Yorubaland', Africa 60 (3): 338-69.

'Tribalism from East to West ...' [review of J.-P. Chrétien et G. Prunier (eds) Les Ethnies ont une histoire]. Journal of African History 31 (1): 152-3.

1991

'Long-dead sociologists and African history', Journal of African History 32: $501-6$.

'Maine as an ancestor of the social sciences' in A. Diamond (ed.), The Victorian Achievement of Sir Henry Maine: a centennial reappraisal. Cambridge: Cambridge University Press, pp. 179-84.

Review of A. Hastings, African Catholicism: essays in discovery. Journal of Religion in Africa 21 (1): 90-2.

Review of L. Spitzer, Lives In Between: assimilation and marginality in Austria, Brazil, West Africa, 1780-1945. Bulletin of Latin American Research 10 (1): 90-1.

Review of P. B. Steinmetz, Pipe, Bible, and Peyote Among the Oglala Lakota: a study in religious identity. American Journal of Sociology 96 (4): 1071-2.

1992

[co-edited with J. F. Ade Ajayi] People and Empires in African History: essays in memory of Michael Crowder. London: Longman, pp. xxv + 254. Also co-author of 'Introduction', pp. xv-xxv. 
Review of M. Bloch, Ritual, History and Power: selected papers in anthropology. Man (N.S.) 27 (2): 419-20.

'The colonization of consciousness' [review of J. Comaroff and J. L. Comaroff, $O f$ Revelation and Revolution, vol 1: Christianity, colonialism and consciousness in South Africa], Journal of African History 33 (2): 328-9.

Review of J. Fabian (ed.), History from Below: the 'Vocabulary of Elisabethville' by Andre Yav: text, translations and interpretive essay. Man (N.S.) 27 (2): 421-2.

1993

'An Africanist revisits Magic and the Millennium' in E. Barker, J. A. Beckford and K. Dobbelaere (eds), Secularization, Rationalism, and Sectarianism: essays in honour of Bryan R. Wilson. Oxford: Clarendon Press, pp. 81-100.

'Between Crowther and Ajayi: the religious origins of the modern Yoruba intelligentsia' in T. Falola (ed.), African Historiography: essays in honour of Jacob Ade Ajayi. Harlow and Lagos: Longman, pp. 64-79.

'Smith, Edwin William', in C. S. Nicholls (ed.) Dictionary of National Biography: missing persons. Oxford: Clarendon Press, pp. 612-13. Revised version in H. C. G. Matthew and B. Harrison (eds) (2004), Oxford Dictionary of National Biography. Oxford: Oxford University Press, vol. 51, pp. 93-4.

Review of A. Biersack (ed.), Clio in Oceania: toward a historial anthropology and of E. Ohnuki-Tierney (ed.), Culture through Time: anthropological approaches. History and Theory 32 (2): 162-78.

Review of J. O'Brien and W. Roseberry (eds), Golden Ages, Dark Ages: imagining the past in anthropology and history. Man (N.S.) 28 (3): 627-8.

1994

'Crowther, Bishop S. A.' in R. E. Asher (ed.), Encyclopedia of Language \& Linguistics. Oxford: Pergamon Press, vol. 2, pp. 795-6.

'Historicity and pluralism in some recent studies of Yoruba religion' [reviews of M. Drewal, Yoruba Ritual: performers, play, agency, of A. Apter, Black Critics and Kings: the hermeneutics of power in Yoruba society and of J. K. Olupona, Kingship, Religion and Rituals in a Nigerian Community: a phenomenological study of Ondo Yoruba festivals], Africa 64 (1): 150-66.

Review of J. Fabian, Time and the Work of Anthropology: Critical essays, 19711991. Africa 64 (3): 435-6. 
Review of R. W. Hefner (ed.), Conversion to Christianity: historical and anthropological perspectives on a great transformation. Bulletin of the School of Oriental and African Studies 57 (2): 453-4.

Review of R. Launay, Beyond the Stream: Islam and society in a West African town. African Affairs 93 (371): 302-3.

Review of P. G. Stromberg, Language and Self-transformation: a study of the Christian conversion narrative. Anthropos 89 (3): 311-12.

1995

'For who hath despised the day of small things? Missionary narratives and historical anthropology', Comparative Studies in Society and History 37 (3): 581-607.

Review of J. Vansina, Living with Africa. Journal of the Royal Anthropological Institute 1 (4): 877.

1996

'Africa, West', in D. Levinson and M. Ember (eds), Encyclopedia of Cultural Anthropology. New York NY: Holt, vol. 1, pp. 20-4.

'Problems and opportunities in an anthropologist's use of a missionary archive' in R. A. Bickers and R. Seton (eds), Missionary Encounters: sources and issues. London: Curzon Press, pp. 70-94.

Review of Africa South of the Sahara 1996. International Affairs 72 (3): 634.

Review of T. D. Blakely, W. E. A. Van Beek and D. Thomson (eds), Religion in Africa: experience and expression. Journal of Religion in Africa 26 (2): 219-21.

'The politicisation of religion in Nigeria: three studies' [review of M. H. Kukah, Religion, Politics and Power in Northern Nigeria, of I. M. Enwerem, A Dangerous Awakening: the politicization of religion in Nigeria and of N. Kastfelt, Religion and Politics in Nigeria: a study in Middle Belt Christianity], Africa 66 (4): 607-11.

Review of E. P. Renne, Cloth That Does Not Die: the meaning of cloth in Bunu social life. Journal of the Royal Anthropological Institute 2 (4): 728-9.

'Missionaries to Yorubaland' [review of B. Salvaing, Les missionaires à la rencontre de l'Afrique au XIXe siècle (Côte des Esclaves et pays yoruba, 18401891)], Journal of African History 37 (2): 317-18. 
'Life and mind of Prophet Harris' [review of D. A. Shank (abridged by J. Murray), Prophet Harris, The 'Black Elijah' of West Africa], Journal of African History 37 (2): 331-2.

1997

'A comparative analysis of Ogun in precolonial Yorubaland' in S. T. Barnes (ed.), Africa's Ogun: old worlds and new. 2nd expanded edition. Bloomington IN: Indiana University Press, pp. 263-89. Revised version in J. Peel, Christianity, Islam, and Orișa Religion (2016), pp. 52-70, 243-50.

'Prophetic movements: overview' in J. Middleton (ed.), The Encyclopedia of Africa South of the Sahara. New York NY: Charles Scribner's Sons, vol. 3, pp. 510-15.

Review of T. Falola and P. E. Lovejoy (eds), Pawnship in Africa: debt bondage in historical perspective. International Journal of African Historical Studies 29 (3): $662-3$.

Review of P. S. Landau, The Realm of the Word: language, gender and Christianity in a Southern African kingdom. Journal of Religion in Africa 27 (2): 194-6.

1998

'Two pastors and their Histories: Samuel Johnson and C. C. Reindorf' in P. Jenkins (ed.), The Recovery of the West African Past: African pastors and African history in the nineteenth century: C. C. Reindoff \& Samuel Johnson. Basel: Basler Afrika Bibliographien, pp. 69-81. Revised version in J. Peel, Christianity, Islam, and Orișa Religion (2016), pp. 38-51, 240-3.

2000

Religious Encounter and the Making of the Yoruba. Bloomington IN: Indiana University Press, pp. xi +420 .

'Yoruba as a city-state culture' in M. H. Hansen (ed.), A Comparative Study of Thirty City-State Cultures: an investigation conducted by the Copenhagen Polis Centre. Historik-filosofiske Skrifter 21. Copenhagen: Royal Danish Academy of Sciences and Letters, pp. 507-17.

'The Moses of African historiography' [review of T. Falola (ed.), Tradition and Change in Africa: the essays of J. F. Ade Ajayi], Journal of African History 43: 532-3.

Review of P. McKenzie, Hail Orisha! A phenomenology of a West African religion in the mid-nineteenth century. Journal of Religion in Africa 30 (3): 401-3.

Review of T. Ranger, Voices from the Rocks: nature, culture and history in the Matopos Hills of Zimbabwe. Journal of Southern African Studies 26 (4): 861-3. 
'Adrian Hastings, 1929-2001: an appreciation', Journal of Religion in Africa 31 (4): 493-503.

'African studies: religion' in N. J. Smelser and P. B. Baltes (eds), International Encyclopedia of the Social and Behavioral Sciences. Amsterdam and Oxford: Elsevier, vol. 1, pp. 259-63.

'Colonialism and Christianity' [review of J. Comaroff and J. L. Comaroff, $O f$ Revelation and Revolution, vol. 2: The dialectics of modernity on a South African frontier], Journal of African History 42 (1): 144-5.

'Christianity and the logic of nationalist assertion in Wole Soyinka's İsarà' in D. Maxwell with I. Lawrie (eds), Christianity and the African Imagination: essays in honour of Adrian Hastings. Leiden: E. J. Brill, pp. 127-55.

'Gender in Yoruba religious change', Journal of Religion in Africa 32 (2): 136-66.

'La réponse aux critiques' [reply to 'Autour d'un livre' review symposium on Religious Encounter and the Making of the Yoruba with T. Ranger, A. Mary and J.-F. Bayart], Politique Africaine 87: 209-14.

Review of J. Sadowsky, Imperial Bedlam: institutions of madness in colonial southwest Nigeria. Journal of Imperial and Commonwealth History 30 (1): 170-1.

Review of O. Vaughan, Nigerian Chiefs: traditional power in modern politics, 1890s-1990s. American Historical Review 107 (3): 986-7.

2003

'The arts and humanities: between history and ethnography' in D. Arnold and C. Shackle (eds), SOAS Since the Sixties. London: School of Oriental and African Studies, pp. 87-108.

Review of A. O'Hear, Power Relations in Nigeria: Ilorin slaves and their successors. Africa 73 (1): 139-40.

'Awolowo, Obafemi' in H. C. G. Matthew and B. Harrison (eds), Oxford Dictionary of National Biography. Oxford: Oxford University Press, vol. 3, pp. 5-6. 
'Divergent modes of religiosity in West Africa' in H. Whitehouse and J. W. Laidlaw (eds), Ritual and Memory: toward a comparative anthropology of religion. Walnut Creek CA: AltaMira Press, pp. 11-30. [Note: some sources cited this work in advance of publication under the title 'Modes of religiosity and dichotomous theories of religion'.] Revised version in J. Peel, Christianity, Islam, and Orisa Religion (2016), pp. 71-87, 250-2.

'Galton Lecture 2003: Spencer in history: the second century' in G. Jones and R. A. Peel (eds), Herbert Spencer: the intellectual legacy: proceedings of a conference organised by the Galton Institute, London, 2003. London: The Galton Institute, pp. 125-49.

'MacRae, Donald Gunn' in H. C. G. Matthew and B. Harrison (eds), Oxford Dictionary of National Biography. Oxford: Oxford University Press, vol. 36, pp. 8-9.

'Nigeria' in H. J. Hillerbrand (ed.), Encyclopedia of Protestantism. New York NY: Routledge, vol. 3, pp. 1401-2.

'Wilson [née Hunter], Monica' [incorporating also Godfrey Baldwin Wilson], in H. C. G. Matthew and B. Harrison (eds), Oxford Dictionary of National Biography. Oxford: Oxford University Press, vol. 59, pp. 619-20.

\section{5}

'Not really a view from without: the relations of social anthropology and sociology' in A. H. Halsey and W. G. Runciman (eds), British Sociology Seen from Without and Within. Oxford: Oxford University Press for the British Academy, pp. 70-93.

Review of O. Olajubu, Women in the Yoruba Religious Sphere. Bulletin of the School of Oriental and African Studies 68 (1): 182-3.

2006

'Foreword' to M. A. Ojo, The End-Time Army: charismatic movements in modern Nigeria. Trenton NJ: Africa World Press, pp. vii-x.

Review of K. M. Clarke, Mapping Yorùbá Networks: power and agency in the making of transnational communities. Bulletin of the School of Oriental and African Studies 69 (1): 196-7.

Review of S. Ellis and G. ter Haar, Worlds of Power: religious thought and political practice in Africa. African Affairs 105 (418): 145-6.

'Foreword' to A. Ukah, A New Paradigm of Pentecostal Power: a study of the Redeemed Christian Church of God in Nigeria. Trenton NJ: Africa World Press, pp. xix-xxiv. 
'Yoruba religion: seeing it in history, seeing it whole', Orita: Ibadan Journal of Religious Studies 40: 1-24.

'Yoruba religion: setting it in history, setting it whole'. Third Ebenezer Adeola Adegbola Memorial Lecture. Ibadan: Institute of Church and Society, pp. 3.

2009

Islam and Christianity through the Prism of Yoruba History. Distinguished Lectures Series. Lagos: Faculty of Arts, University of Lagos, pp. iv +23 .

'Postsocialism, postcolonialism, Pentecostalism' in M. Pelkmans (ed.), Conversion after Socialism: disruptions, modernism and technologies of faith in the former Soviet Union. New York NY: Berghahn Books, pp. 183-99. Revised version in J. Peel, Christianity, Islam, and Orișa Religion (2016), pp. 88-102, 252-4.

'A heterogeneous volume of Yoruba history and culture' [review of T. Falola and A. Genova (eds), The Yoruba in Transition: history, values, and modernity], Journal of African History 50 (1): 148-9.

Review of P. Worsley, An Academic Skating on Thin Ice. Journal of the Royal Anthropological Institute 15 (3): 637-8.

2010

'Yoruba religion as global phenomenon' [review of J. K. Olupona and T. Rey (eds), Orìsà Devotion as World Religion: the globalization of Yorùbá religious culture], Journal of African History 51 (1): 107-8.

2011

[with D. J. Smith, J. Robbins, J.-F. Bayart and R. Marshall] 'An author meets her critics: around Political Spiritualities: the Pentecostal revolution in Nigeria by Ruth Marshall', Religion and Society: Advances in Research 2: 138-57.

'Un siècle d'interactions entre islam et christianisme dans l'espace yoruba', Politique Africaine 123: 27-50. Revised English-language version in J. Peel, Christianity, Islam, and Orișa Religion (2016), pp. 172-91, 273-7.

Review of J. Goble, Palm Oil and Small Chop. International Journal of Maritime History 23 (2): 408-9.

'Retrieving Spencer' [review of J. Offer, Herbert Spencer and Social Theory], European Journal of Sociology 52 (3): 577-9. 
Review of A. Masquelier, Women and Islamic Revival in a West African Town. Journal of the Royal Anthropological Institute 17 (3): 665-6.

Review of R. Sarró, The Politics of Religious Change on the Upper Guinea Coast: iconoclasm done and undone. Etnografica 15 (2): 395-9.

Review of O. Taiwo, How Colonialism Preempted Modernity in Africa. Africa 81 (3): 517-18.

Review of J. E. Tishken, T. Falola and A. Akinyemi (eds), Sango in Africa and the African Diaspora. Africa 81 (2): 340-1.

2013

'Los tres círculos de la religión yoruba', Caminos: revista cubana de pensamiento socioteológico 68-9: 32-9.

2014

Book debate [with M. A. Noll, J. Willis and D. R. Peterson] on D. R. Peterson, Ethnic Patriotism and the East African Revival: a history of dissent c.1935-1972. Social Sciences and Missions 272-5 (2-3): 267-80.

Review of T. E. Hucks, Yoruba traditions and African American religious nationalism. American Historical Review 119 (5): 1713-14.

2015

Christianity, Islam, and Orisa Religion: three traditions in comparison and interaction. Oakland CA: University of California Press, pp. 312.

'George Clement Bond, 1936-2014', Africa 85 (1): 183-4.

'J. F. Ade Ajayi: a memorial', Africa 85 (4): 745-9.

'Preface: a drummer's tale: Àjàká of Òtà' in A. Villepastour (ed.), The Yorùbá God of Drumming: transatlantic perspectives on the wood that talks. Jackson MI: University Press of Mississippi, pp. ix-xxv.

Review of T. S. Drønen, Pentecostalism, Globalisation, and Islam in Northern Cameroon: megachurches in the making? PentecoStudies: An Interdisciplinary Journal for Research on the Pentecostal and Charismatic Movements 14 (1): 144-5.

Review of E. M. Hogan, Cross and Scalpel: Jean-Marie Coquard among the Egba of Yorubaland. Social Sciences and Missions 28 (3-4): 407-8. 
2016

'Similarity and difference, context and tradition, in contemporary religious movements in West Africa'. Africa 86 (forthcoming).

Letters from Liberia. London: International African Institute and SOAS, University of London (forthcoming).

RICHARD BARTHOLOMEW

RICHARD BARTHOLOMEW received his $\mathrm{PhD}$ in the study of religion from SOAS in 2003. He is a freelance copyeditor and researcher and is accredited with the UK Society of Indexers. Email: barthbookwork@gmail.com 